\title{
Rolnictwo miejskie jako innowacyjna produkcja stanowiąca element scalający i uzupelniający strukturę miasta
}

\author{
Magdalena Grochulska-Salak
}

\author{
Katedra Urbanistyki i Gospodarki Przestrzennej, Wydziat Architektury, Politechnika Warszawska, \\ e-mail:m.grochulska-salak@o2.pl
}

Streszczenie: Rolnictwo miejskie definiowane jest jako zabudowa realizowana do produkcji roślin na potrzeby społeczności lokalnej. Prezentowana problematyka dotyczy kształtowania zabudowy wraz z systemami zieleni dla zachowania środowiskowej równowagi przestrzeni miejskich oraz powiązań dotyczących współistnienia architektury i zieleni w mieście. Wskazuje się na możliwość kształtowania synergicznych układów przestrzennych poprzez integrację przestrzeni miejskiej i zabudowy o innowacyjnej funkcji produkcji - farmy miejskiej - stanowiącej uzupełnienie struktury funkcjonalnej miasta w powiązaniu z kształtowaniem przestrzeni publicznych i systemu zieleni. Architektura pro-środowiskowa powiązana z technologiami umożliwiającymi produkcję roślin w budynkach, umożliwia integrację przestrzeni miejskiej uzupełniając strukturę funkcjonalno-przestrzenną miasta. Wdrażanie nowych technologii umożliwia realizację produkcji roślin w budynkach farm hydroponicznych i aeroponicznych. Technologia produkcji oraz program i struktura zabudowy farmy miejskiej stanowią przedmiot badań i analiz, w celu ukształtowania zabudowy zintegrowanej z przestrzenią miejską w kontekście autarkii jednostki urbanistycznej. Wskazuje się na konieczność zwiększenia zakresu produkcji dóbr materialnych i niematerialnych realizowanych w zespole farmy miejskiej. Powiązanie z przestrzeniami publicznymi oraz realizacja zabudowy o funkcji użyteczności publicznej uzasadnione jest kształtowaniem programu zagospodarowania terenu i zabudowy na potrzeby społeczności lokalnej. Farma miejska może stanowić element scalający strukturę miasta. Powinna być realizowana w miejscach węzłowych w powiązaniu z systemami: komunikacji drogowej, przestrzeni publicznych oraz zieleni miejskiej.

Słowa kluczowe: Rozwój harmonijny, nowa urbanistyka, rolnictwo miejskie, farmy miejskie, farmy wertykalne, architektura zielona.

\section{Wprowadzenie}

Analiza innowacyjnych rozwiązań technologicznych zintegrowanych z zabudową oraz obserwowane procesy przemian struktur miejskich, społecznych i środowiskowych, dają podstawy do formułowania wniosków i wytycznych na potrzeby wprowadzanej nowej funkcji w tkance miejskiej - produkcji roślin na potrzeby społeczności lokalnej, określanych jako rolnictwo miejskie. Podstawowym założenie niniejszego opracowania jest twierdzenie, że w strukturze miejskiej można realizować produkcję roślinności w celach żywieniowych dla mieszkańców miasta. Produkować można różne dobra materialne (roślinność) i niematerialne (prąd).

Kolejną tezą jest twierdzenie, że produkcja roślin może być realizowana w budynkach i na terenach w strukturze miasta, w miejscach węzłowych oraz poprzemysłowych terenach 
stanowiących obecnie rezerwy dla nowych funkcji wprowadzanych w procesie rewitalizacji terenów i obiektów zdegradowanych.

W niniejszym opracowaniu wskazane zostały 3 zagadnienia szczegółowe podlegające rozpoznaniu:

1. Rolnictwo miejskie jest innowacyjną produkcją - nową funkcją produkcji roślin, realizowaną w mieście dzięki zastosowaniu nowatorskich rozwiązań technologicznych zintegrowanych $\mathrm{z}$ budynkiem.

2. Zagospodarowanie terenu i zabudowa na rzecz produkcji roślin $\mathrm{w}$ mieście mogą stanowić uzupełnienie struktury funkcjonalnej współczesnego miasta.

3. Rolnictwo miejskie realizowane w „miejscach węzłowych” może być elementem scalającym strukturę miasta oraz determinującym jego rozwój i kierunek przekształceń.

W niniejszym opracowaniu prezentowane są wnioski z pracy badawczej dotyczącej problematyki ,rolnictwa miejskiego”, wskazując na zagadnienia:

- Problematyka rolnictwa miejskiego, jako nowej funkcji w strukturze miasta

- Typologia farm miejskich

- Farmy miejskiej jako uzupełnienie struktury funkcjonalno-przestrzennej miasta

- Podsumowanie problematyki rolnictwa miejskiego jako elementu scalającego i uzupełniającego strukturę funkcjonalną i przestrzenną miasta

Wdrażanie nowych technologii i założeń produkcyjnych prowadzi do upowszechnienia rozwiązań i przemian prowadzących do powstawania nowych dyscyplin i rozwoju dydaktyki w oparciu o postęp ideologiczny i technologiczny. Impulsem inicjującym jest myśl techniczna i dostępne technologie oraz uwarunkowania rynkowe i społeczne. Opisanie procesów oraz kierunków zmian, warunkują rozwój w usprawnianej dziedzinie.

Przemyst, który produkuje, przetwarza i sprzedaje żywność, paliwo i inne produkty uboczne w celu zaspokojenia dziennego zapotrzebowania konsumentów w obrębie śródmieścia, miasta czy metropolii, gospodarujac na terenach prywatnych i publicznych $w$ granicach miasta. Zazwyczaj stosuje intensywne metody produkcji, przy wykorzystaniu naturalnych źródet energii i recyklingu odpadów miejskich, produkując, przetwarzajac i sprzedajac żywność w sposób bezpieczny, zdrowy, a jednocześnie tworzac naturalne środowisko miejskie [1].

Innowacyjne myślenie nie zawsze polega na stworzeniu lub odkryciu czegoś zupełnie nowego, ale bazuje na nowym wykorzystaniu, połączeniu lub ukształtowaniu, dającym nowe możliwości rozwoju myśli i technologii. ,, Idea współdziałania trzech odrębnych stref: ekonomii, środowiska oraz wartości społecznych, nie jest teoria unikatowa - cenna jest natomiast próba zinterpretowania wspólnych dla nich celów [2]. Realizacja farm miejskich oraz procesy przemian społecznych i urbanistycznych dają podstawy do twierdzenia, że powstaje pionierski nurt w urbanistyce i architekturze, wpisujący się w założenia Nowego Planowania. Wdrażanie innowacyjnych rozwiązań technologicznych oraz myśli planistycznych będących wyrazem rozwoju cywilizacji, warunkują nowatorskie myślenie o strukturze miejskiej i zabudowie integrującej różne funkcje, technologie i materiały z wykorzystaniem zieleni jako elementu kompozycyjnego elewacji i dachów. Wnętrza urbanistyczne, przestrzenie publiczne i zabudowa kształtowane są w sposób zintegrowany, w którym roślinność, woda i energia stanowią elementy kompozycyjne, materiał wykończeniowy oraz efekt produkcji na potrzeby społeczności lokalnej.

Termin Nowe Planowanie określa te zmiany w urbanistyce, które zmierzaja do dywersyfikacji przestrzeni $w$ zgodzie z rosnacym zapotrzebowaniem na owo zróżnicowanie. Termin ten powstat, aby nadać nazwę temu, co w planowaniu i projektowaniu miast wymaga 
odnowienia i jest odnawiane. Nowe Planowanie to odpowiedź planistów na coraz szybciej zachodzace zmiany w otaczajacym nas świecie. Chodzi tu o nowa geografie miast, ich obywateli, problemy ideologiczne itd. [3]. Odpowiadając na potrzeby cywilizacyjne i społeczne konieczne jest kształtowanie przestrzeni miejskiej z uwzględnieniem nowych technologii i funkcji wprowadzanych do struktury miasta. Nowe Planowanie to stajacy się na naszych oczach i przy naszym udziale fakt. Oto czas, jedna z najważniejszych determinant rozwoju miast, coraz bardziej przyspiesza zmiany w otaczajacym nas świecie zachodza coraz szybciej. Tempo tak rośnie, że często nie mamy czasu na reakcję, co powoduje stopniowa utrate kontroli nad wydarzeniami [4]. Konieczna jest analiza inwestycji wprowadzających nowe funkcje w strukturze miasta oraz synteza umożliwiająca planowanie systemów i programowania nasycenia struktury miejskiej nowymi funkcjami wprowadzanymi do systemu przestrzeni miejskiej i społecznej.

Tak więc koncentrować się powinniśmy nie na zmianie rzeczywistości, ale na badaniu i ujawnianiu nowych możliwości, jakie daja zachodzace procesy. Kierunkiem działania być powinno tworzenie nowych krajobrazów miejskich $w$ przestrzeni znajdującej się pomiędzy dotychczasowymi centrami miejskimi, która dotychczas nazywaliśmy otwarta, a czasem pusta lub negatywowa. Tym samym tę pusta dotychczas przestrzeń, użytkowana spontanicznie $i$ dość dowolnie, a nawet nadużywana czy zużywana, podnosimy do rangi takiej samej, jaka mają obszary zabudowane [5]. Na „rezerwach terenowych” oraz terenach poprzemysłowych ulegających stopniowej degradacji pojawia się możliwość realizacji rolnictwa miejskiego, stanowiącego produkcję i przetwarzanie roślin użytkowych przeznaczonych dla społeczności lokalnej. Uwzględnienie tych przekształceń w Nowym Planowaniu, umożliwi wprowadzanie nowej funkcji w miejskich obszarach węzłowych.

\section{Problematyka rolnictwa miejskiego jako nowej funkcji w strukturze miasta}

Tezą wskazaną już na wstępie jest twierdzenie, że produkcja roślinności użytkowej stanowi zagadnie urbanistyczne. Zatem wskazuje się na współzależność produkcji roślinności z procesami urbanizacji, tj. przekształcania siedlisk ludzkich w strukturę miasta i jego dalsze przekształcenia w wyniku rozwoju cywilizacji. Jako podstawę rozpoznania wskazuje się rolnictwo miejskie, rozumiane jako przekształcenie środowiska naturalnego oraz kształtowanie przestrzeni i formowanie zabudowy w celu uprawy roślin użytkowych, tj. produkcji i hodowli wybranych przez człowieka gatunków roślin przeznaczonych na potrzeby żywieniowe i użytkowe społeczności lokalnych żyjących w mieście. Autorska definicja zagadnienia przedstawiona na potrzeby formowanego problemu badawczego, dotyczy kształtowania zabudowy i przestrzeni w strukturze miasta tj. uprawy roślin w strukturze miejskiej oraz wprowadzania rozwiązań inżynieryjnych w celu realizacji terenów biologicznie czynnych będących integralną częścią zabudowy. Jest to kierunek rozwijający się, wymagający współpracy specjalistów z wielu dziedzin związanych z urbanistyką, architekturą, budownictwem, naukami przyrodniczymi, ekonomicznymi oraz socjologią.

Innowacyjne jest już stosowanie określenia zjawiska jako „,Rolnictwo miejskie”, które wydaje się pozostawać w sprzeczności z dotychczasowym definiowaniem oraz klasyfikacjami zagospodarowania przestrzeni i funkcji terenów miejskich. Rolnictwo dotychczas na ogół rozumiane było, jako działalność prowadzona poza miastem, na terenach wiejskich z gruntami rolnymi. Tymczasem miasto przeważnie definiowano jako obszary zurbanizowane, zagospodarowane na cele inne niż rolne. Miasto definiuje się na wiele sposobów, w tym: 
Z socjologicznego punktu widzenia, miasto to nie tylko domy, ulice, place i gmachy publiczne, ale przede wszystkim ludzie. Społeczność mieszkańców miast wytwarzała w ramach swoich działalności gospodarczych przeróżne dobra materialne, przy ich pomocy urzadzane byto odpowiednie środowisko zamieszkania, tworzace specyficzny typ krajobrazu miejskiego [6].

Wskazać należy, że „Kryzys miasta stworzyt lawinowy rozwój badań interdyscyplinarnych. Jednocześnie zanika jak pisze Wallis: wielka historiozoficzna refleksja nad pojęciem „miasto", które niefrasobliwie stosuje się wymiennie z pojęciem ,tereny zurbanizowane” [7].

Literatura wskazuje, że urbanizacja, to: Proces kształtowania się miejskich układów osadniczych mogących tworzyć różne formy strukturalne związane z miejskim stylem życia. Przyczyny urbanizacji wynikaja ze statego rozwoju cywilizacji miejskich oraz przyrostu liczby ludności miejskiej. Przejawia się to rozwojem terytorialnym i ludnościowym miast istniejacych dzięki powstawaniu stref zabudowy nierolniczej na obszarach aglomeracji i konurbacji miejskich, a także przez powstawanie nowych miast i osiedli [8]. Urbanistyka jako nauka zajmująca się badaniem i planowaniem powstawania i rozwoju jednostek osadniczych wskazując za podstawowy proces urbanizację, determinuje kształtowanie struktury funkcjonalnej miasta i aglomeracji. Rolnictwo spełnia podstawowe zadanie dla społeczności mieszkającej w mieście, zapewnia wyżywienie. Jednakże w dotychczas formowanych definicjach dotyczących produkcji roślinności, nie brano pod uwagę możliwości realizacji jej w strukturze miejskiej, choć zadania te były i są na obszarze miasta realizowane.

Architekturę początku XX wieku zdominowata fascynacja przemystem i nowymi technologiami. Szybka zmiana nastapita wraz z nadejściem ery informacji i ekologii [9]. Wskazać zatem należy iż literatura zajmująca się rozwojem struktur społecznych i struktur miejskich, powinna podążać za rozwojem osiągnięć cywilizacyjnych i aktualizować podstawowe definicje uwzględniając i nie wykluczając produkcji roślinności w przestrzeni i zabudowie miejskiej. Ekologia jako nauka pokazała środowisko naturalne z szerszej perspektywy, badając zachodzace w nim procesy z niespotykana wcześniej dokładnościa. Stała się także inspiracja dla nowej architektonicznej ikonografii [10]. Dzięki interdyscyplinarnym pracom badawczym opierającym się na rozpoznaniu procesów i zależności ekosystemów oraz rozwojowi technologii i budownictwa możliwe stało się integrowanie działań zmierzających do poprawy parametrów środowiskowych i warunków życia w mieście.

Ekologia uwarunkowała w ostatnich czasach wszelkie przedsięwzięcia i zachowania. Prezes Worldwatch Institute Lester Brown tak opisat ten epokowy przełom: ,, To prawdziwa rewolucja w podejściu do środowiska naturalnego. Ekonomiczne i społeczne przemiany, które można porównać z rewolucjami rolna i przemystowa". Architektura motywowana przez ego zostata zdeprecjonowana i zastapiona przez architekturę odpowiedzialna spolecznie i zintegrowana ze środowiskiem. (...) [11].

Wyrazem tego niewątpliwie jest realizacja rolnictwa miejskiego, rozumiane jako kształtowanie przestrzeni i formowanie zabudowy przemysłowej w celu produkcji i hodowli wybranych przez człowieka gatunków roślin przeznaczonych na potrzeby żywieniowe i użytkowe dla społeczności w mieście.

Wprowadzanie rolnictwa w mieście możliwe jest dzięki użyciu odpowiedniej technologii farm miejskich. Prototypowe budynki tego typu (w tym farmy wertykalne) są realizowane, a produkty są wprowadzane na rynek konsumencki. Obserwować można formowanie nowego zjawiska w procesie urbanizacji i rozwoju społeczeństwa oraz nowego sposobu myślenia o kształtowaniu budynków wraz z elementami zieleni, stanowiącymi integralną część zabudowy. Niezależnie od tego, czy prognozy i śmiałe wizje będą wdrożone lokalnie, czy globalnie, farmy miejskie i zabudowa farm wertykalnych są już realizowane, przez 
swoje istnienie oddziałują i inspirują do dalszych działań. Kształtowanie zabudowy tego typu oraz nowego typu inwestycji i formy zabudowy, jako zjawisko globalne będzie do oceny w dłuższej perspektywie czasu, jednakże współczesne realizacje świadczą o zasadności badań oraz analiz zagadnienia. Halina Skibniewska wskazywała: , W miastach żyje ponad połowa ludności świata. Mimo kryzysu miast i często dramatycznej degradacji warunków życia - miasto ofiaruje cenna różnorodność, stymulacje, pożądane wybory, ciagłość kultury i możliwość obcowania z natura. Świeże powietrze, czysta woda, cisza, otoczenie żywej przyrody, ekonomia zasobów i energii - mogą być cechą życia w mieście. (...) Uważa się, że tylko proekologiczne planowanie może zminimalizować destrukcję drzew powietrza $i$ wody. (...) Dziś szukamy nowej formuly: zintegrowanego planowania miasta, gdzie będa wspólżyty $w$ harmonii $i$ we wzajemnym poszanowaniu konieczne do życia ciagłe systemy przyrody $i$ systemy techniczne, wprowadzane przez człowieka - nowa ko habitacja przyrody i techniki. Systemy ekologiczne sa bardzo tradycyjne i mato adaptowalne. Systemy techniczne z natury bardziej fleksyjne, dzięki inteligencji człowieka moga uwzględniać wieczne prawa natury: ciagłość systemów ekologicznych $w$ czasie i przestrzeni, bioróżnorodność, zgodność z podtożem. (...) Dziś szukamy rozwiązań, w których prawa natury - swoiste sacrum - wpisane sa w ustrój przestrzenno-społeczny miasta, zgodnie z przesłankami ekorozwoju, wprowadzonymi do naszego prawodawstwa" [12]. Dzięki rozwojowi technologii oraz działalności naukowej i dydaktycznej, powstają teorie pro środowiskowego kształtowania terenów zurbanizowanych i rozpowszechniane są wytyczne w sprawie gospodarowania nieodnawialnymi surowcami. ,W skali urbanistycznej problematyka zachowania surowców nieodnawialnych, $w$ tym energetycznych, nie jest celem samym $w$ sobie. Jest natomiast fragmentem szeroko rozumianej zintegrowanej strategii, która zakłada wdrożenie zasad środowiska zrównoważonego, przy uwzględnieniu lokalnego, regionalnego i globalnego wpływu przekształcanych obszarów na: glebę, powietrze, roślinność, faunę oraz ludzka populację." [13].

Obserwowany jest proces ponownego wprowadzania zieleni do miast, wskazuje się na jej znaczenie nie tylko estetyczne ale i użytkowe oraz wpływ na funkcjonowanie miasta i regulację parametrów środowiskowych. W efekcie upowszechnienia wyników badań i zwiększenia świadomości społecznej dotyczącej problemów środowiskowych formowane zostały ruchy ekorozwoju: architektoniczne, filozoficzne i psychologiczne. Ukształtowany został nurt architektury zielonej, pro- środowiskowej zintegrowanej z otoczeniem i wkomponowanej w krajobraz naturalny oraz kontekst miejski. Formuła architektonicznego kształtowania „,budynków zielonych” jest propagowana i realizowana przez architektów i urbanistów na rzecz zrównoważonego rozwoju. Realizowane są obiekty o różnym przeznaczeniu i wielkości mające jednak wspólne założenia ideowe: optymalizacja, integracja technologii, minimalizacja ingerencji w środowisko, wkomponowanie w krajobraz, stosowanie materiałów naturalnych oraz roślinności jako elementu budynku. Nawet najwięksi zwolennicy ekologii zmagaja się z problemem powiazania trzech kwestii: przyjaznej środowisku technologii, oszczędności surowców $i$ wartości estetycznych. Tylko wspótistnienie tych trzech komponentów gwarantuje powstanie prawdziwie trwałej architektury [14].

Kształtowanie struktur miejskich oraz zabudowy powinny uwzględniać współczesne założenia zrównoważonego rozwoju bazujące na odnawialnych źródłach energii oraz autarkii jednostek urbanistycznych. Podstawą Nowej Urbanistyki i współczesnego kształtowania miasta, powinna być samowystarczalność polegająca na zaspokojeniu wszelkich potrzeb zarówno konsumpcyjnych, jak i produkcyjnych realizowanych w ramach struktury miejskiej. Wskazuje to na zasadność realizacji rolnictwa miejskiego i produkcji żywności w pro-środowiskowych farmach miejskich powstających strukturze miasta w fazie transformacji. 


\section{Typologia farm miejskich}

W związku z coraz częściej prezentowanymi wynikami analiz problemu żywności w ujęciu globalnym i lokalnym, prowadzone są prace nad intensywną i wydajną uprawą w mieście. „Żywność dla naszej cywilizacji jest kluczowa, bez niej byśmy nie istnieli jednakże w tych czasach kiedy to system zajmuje się dostarczaniem żywności do miast jesteśmy od niego uzależnieni. Ceny żywności sa też wskaźnikiem, w którą stronę idzie nasza cywilizacja, brak zapasów żywności spowodowało upadek już nie jednej cywilizacji dlatego warto jest wziąc pod uwage fakt, że w ostatnich 10 latach ceny żywności zwiększyly się dwukrotnie co z kolei pokazuje wage problemu i w którym kierunku idzie ten system. (...) Kolejnym ważnym wskaźnikiem jest to, że po raz $6 \mathrm{w}$ ciagu 11 lat, ludzkość spożywa więcej niż wyprodukowała, ceny żywności sa rekordowo wysokie i caty czas rosna. Więc póki co nowa era ludzkości zacznie się od światowych problemów z żywnościa i jeżeli nie pojawia się innowacyjne i rewolucyjne pomysty owe problemy moga stać się jeszcze gorsze [15].

Zagospodarowanie terenu, powierzchni lub budynku w celu uprawy roślinności oraz hodowli zwierząt w mieście określane jest jako, farmy miejskie (urban farming). Współcześnie realizowana jest zróżnicowana forma uprawy roślin w mieście. Uprawa roślin w skali przemysłowej - produkcja jest możliwa dzięki zastosowaniu nowej technologii związanej $\mathrm{z}$ hodowlą roślin bez ziemi, w płynącej wodzie (hydroponika) lub w aerozolach wodnych (aeroponika). Wydajność produkcji może być podniesiona dzięki uniezależnieniu od światła naturalnego - słonecznego. Możliwość taka zaistniała gdy stworzono oświetlenie ledowe, o barwie zbliżonej do słonecznego światła warunkującego procesy fotosyntezy oraz odkryciu, że wzrost roślin jest możliwy przy wykorzystaniu diod niebieskich i czerwonych. Rozpoznanie procesów biochemicznych oraz ustanowienie warunków brzegowych i rozwiązań technologicznych umożliwiły wdrożenie rozwiązań i rozpoczęcie hodowli roślin różnych gatunków w farmach wertykalnych oraz wewnątrz budynków produkcyjnych. Prowadzone są badania nad optymalizacją produkcji roślin jako pożywienia oraz nośnika energii, odnawialnego źródła energii.

Postęp techniczny jest zatem ściśle powiązany z uwarunkowaniami realizacyjnymi i sposobem kształtowania farmy miejskiej. Prowadzone są prace nad poprawą wydajności uprawy roślin oraz nad zmniejszeniem zużycia wody i gruntów oraz uniezależnienie od czynników atmosferycznych w tym klęsk żywiołowych oraz skutków zanieczyszczenia środowiska. Eksperymentalnie wprowadza się uprawę roślin do budynków w mieście, stosując uprawy hydroponiczne i aeroponiczne. Tworzenie i udoskonalanie nowych technologii umożliwia uprawę roślin w budynku, przy braku światła dziennego lub przy ograniczonym dostępie do naturalnego oświetlenia. Hodowlę roślin uniezależniono również od gleby. Jedna z metod takich hodowli nazywa się hodowla aeroponiczna co do tej pory mogło kojarzyć się z dziwna zagadkowa hodowla w laboratorium. Jednak uprawa aeroponiczna wbrew pozorom jest prosta - polega ona na dostarczaniu mikro i makro elementów $i$ wszystkich minerałów w powietrzu za pomoca mgły rozpylanej na korzenie roślin. Urządzenia działaja w sposób automatyczny wystarczy dodawać wodę do mieszanki odżywczej i rozłożyć nasiona na specjalnej gąbce a reszta zajmie się urządzenie. W ten sposób rośliny dostają idealne ilości pożywki i rosna znacznie szybciej [16].

O randze zagadnienia świadczy już fakt możliwości stworzenia typologii opisującej zjawisko społecznych inicjatyw oraz realizacji komercyjnych wprowadzanych w struktury miasta na świecie. Analiza zjawiska urban farming i realizacji farm miejskich pozwala wyróżnić 3 podstawowe typy zagospodarowania terenu i zabudowy na potrzeby uprawy roślin w mieście: 
1. Uprawa roślin sadzonych $\mathrm{w}$ ziemi, na otwartej przestrzeni $\mathrm{w}$ gruncie rodzimym, w donicach z ziemią lub na elementach budynków (ścianach, dachach, stropodachach).

2. Uprawa roślin sadzonych w ziemi realizowana wewnątrz budynku, przy zastosowaniu różnego typu donic i rozwiązań technologicznych nawadniających, oświetlających i utrzymujących właściwe - optymalne - parametry środowiska wewnątrz budynku.

3. Produkcja roślin w budynkach i bez wykorzystania ziemi. Wysoce wyspecjalizowana technologia budynków do produkcji roślin bazuje na stworzeniu warunków wzrostu i wegetacji roślin w sposób uprzemysłowiony, w warunkach kontrolowanych przez człowieka, zgodnie z przyjętą technologią i ustalonymi parametrami.

Ruch społeczny i potrzeby mieszkańców miast koncentrują się na realizacji uprawy $\mathrm{w}$ mieście $\mathrm{w}$ sposób zbliżony do tradycyjnego, tj. w ziemi, korzystając $\mathrm{w}$ pełni ze światła naturalnego, będąc zdanym na warunki atmosferyczne, a tym samym również narażając żywność na szkodliwe substancje i zanieczyszczenia występujące w mieście. Uprawa taka w mieście realizowana jest na publicznych terenach zielonych oraz w przestrzeni półpublicznej organizowanej przez społeczność lokalną. W przestrzeni miejskiej, na terenach poprzemysłowych i zdegradowanych powstają społeczne farmy miejskie, gdzie mieszkańcy wspólnie uprawiają warzywa i owoce. Przykładem jest ogród użytkowy na terenach poprzemysłowych w Todmorden w Anglii [17]. Odnotowywane są również uprawy w niekonwencjonalnych miejscach, wykorzystujące powierzchnię dachu lub ściany budynku. Przykładem może być farma miejska na dachu budynku drukarni pod Manchesterem [18].

$\mathrm{Na}$ dachu opuszczonego budynku drukarni pod Manchesterem, zrealizowano eksperymentalną farmę, w której grzyby rosną na kawie, a ryby pomagają uprawiać sałatę. Tego typu realizacje są również w Nowym Jorku, na dachach budynków i pionowych konstrukcjach budynków. Miejska farma na dachu biurowca RK / Riverpark Farm [19].

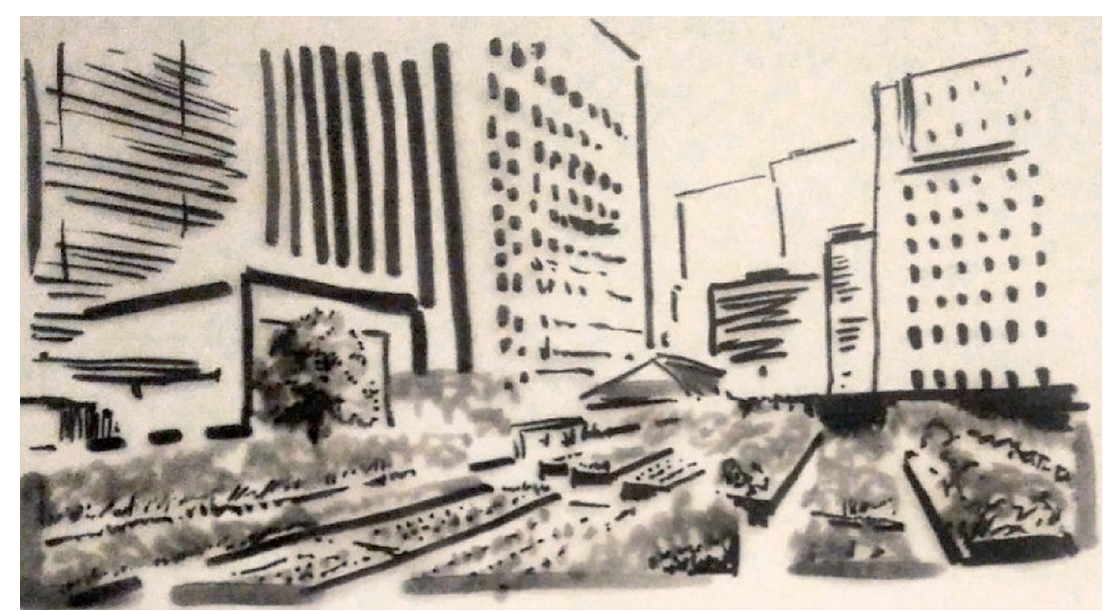

Rys. 1. Miejska farma na dachu biurowca RK / Riverpark Farm

Pracując nad efektywnością i wydajnością produkcji roślin tworzone są technologie służące uprawie w budynkach, w warunkach kontrolowanych i wolnych od skażenia. Hodowla roślin została również zrealizowana w biurowcu w Tokio w Japonii [20]. W 2010 roku japońska firma Pasona, zajmująca się rekrutacją pracowników, zasiedliła biurowiec w samym centrum Tokio. Dziewięciopiętrowy budynek został uprzednio zaprojektowany i zaadaptowany, 
by poza przestrzenią biurową jego znaczną część zajmowały rośliny uprawne. Biurowiec stał się swoistą miejską farmą. Już z zewnątrz wyróżnia się zieloną elewacją i ogrodem na dachu. W niewielkich balkonach posadzono kwitnące krzewy, które ożywiają ściany biurowca, a na dachu drzewka i krzewy owocowe oraz warzywa. Wewnątrz budynku jest prawie 20000 metrów kw. powierzchni, w tym prawie 4000 metrów kw. zajmują grządki, poletka porośnięte 200 gatunkami owoców, warzyw, ziół i zbóż. Wszystkie zebrane plony wykorzystywane są w biurowej restauracji, stanowiąc przykład zjawiska określanego ,, z farmy na stót” (farm-to-table). Rośliny uprawiane są zarówno tradycyjnie w glebie, jak i przy użyciu najnowszych technologii takich jak hydroponika. Wszystko pod nadzorem specjalistów z dziedziny rolnictwa oraz monitoringu inteligentnego systemu sterowania wilgotności, temperatury, nawadniania i oświetlenia.

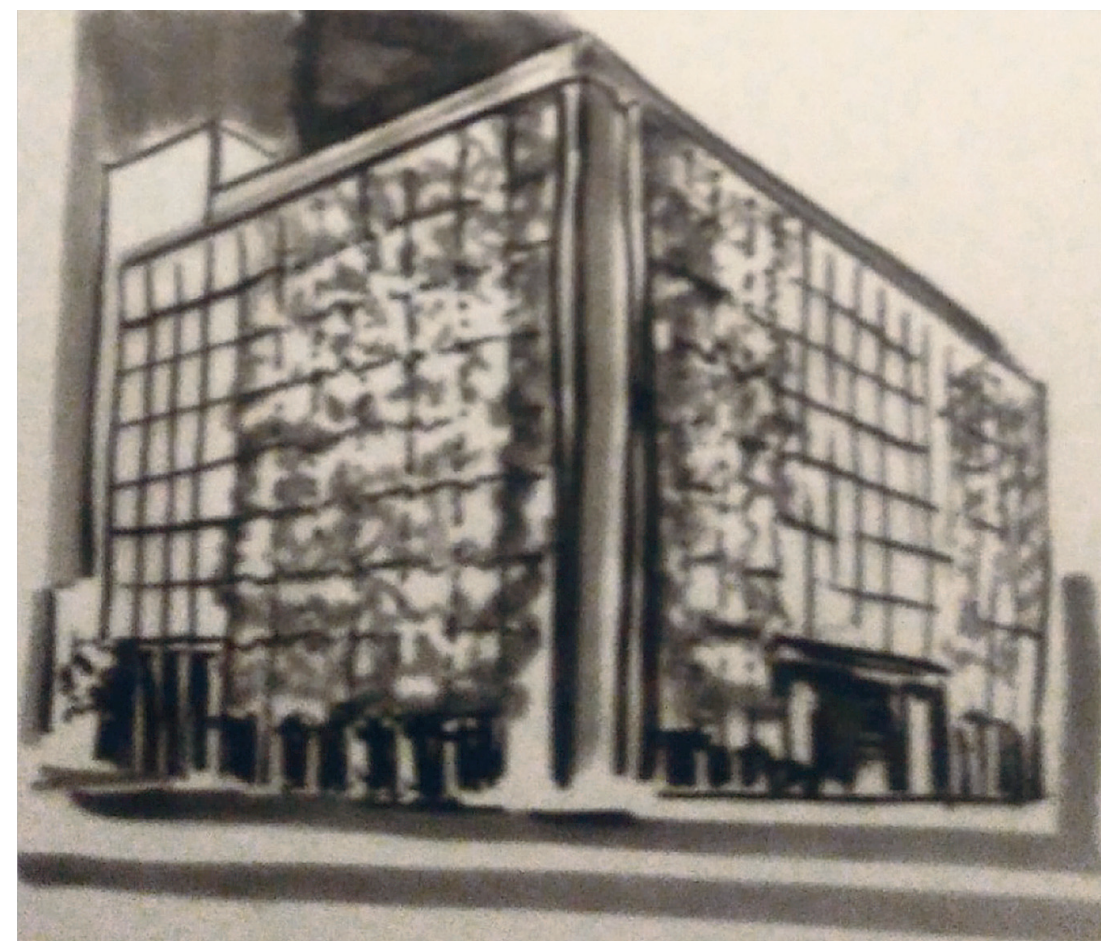

Rys. 2. Zielona ściana farmy w biurowcu w Tokio w Japonii

Miejskie farmy to niedaleka przyszłość, prawdopodobnie nie zastąpią tradycyjnego rolnictwa, ale farmy wertykalne i uprawa metodami uprzemysłowionymi wewnątrz budynków stanowić będą uzupełnienie systemu produkcji rolnej, oferując produkt o konkretnych parametrach i powstały w kontrolowanych warunkach. Prace nad zwiększeniem wydajności $\mathrm{z}$ upraw hydroponicznych i metodami produkcji roślin, aktualnie są wdrażane $\mathrm{w}$ zabudowie realizowanej w miastach uzależnionych od importu żywności oraz o małych zasobach gruntów rolnych. Przykładem jest farma w Japonii zrealizowana w budynku po fabryce Sony [21].

Jak wynika z analiz eksperymentalnego rozwiązania, ,budynek - farma jest 100 razy bardziej produktywna niż tradycyjna uprawa zewnętrzna (...) przy zużyciu wody o $99 \%$ mniejszym niz przy uprawie na zewnątrz. 
Również $w$ Hong Kong'u zrealizowana jst “Fabryka jedzenia” zajmuje powierzchnię zabudowy $2500 \mathrm{~m}^{2}$, wykorzystano 17,500 oświetleń LED, specjalnie zaprojektowanych przez GE. Szybko rosnące warzywa, mogą być transportowane do pobliskich sklepów. Kolejne takie inwestycje planowane są w Rosji, Chinach i Mongolii. AeroFarm-Old New Jersey Factory to House Earth's Largest Vertical Farm [22] jest przykładem wertykalnej farmy miejskiej w budynku. Rośliny produkowane są z wykorzystaniem technologii aeroponiki w budynkach o powierzchni $69000 \mathrm{~m}^{2}$.

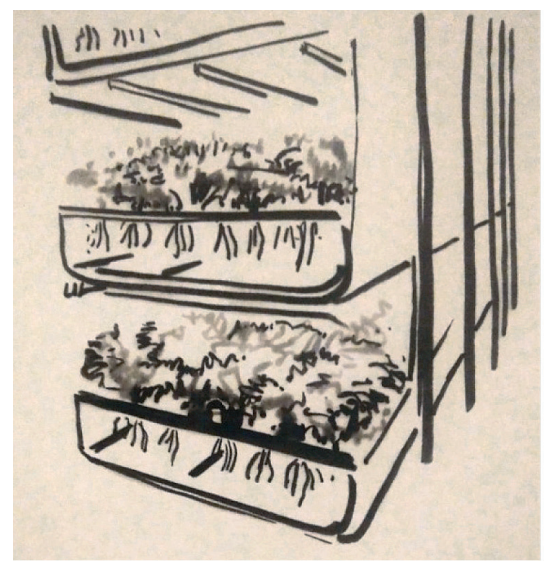

Rys. 3. Uprawa aeroponiczna

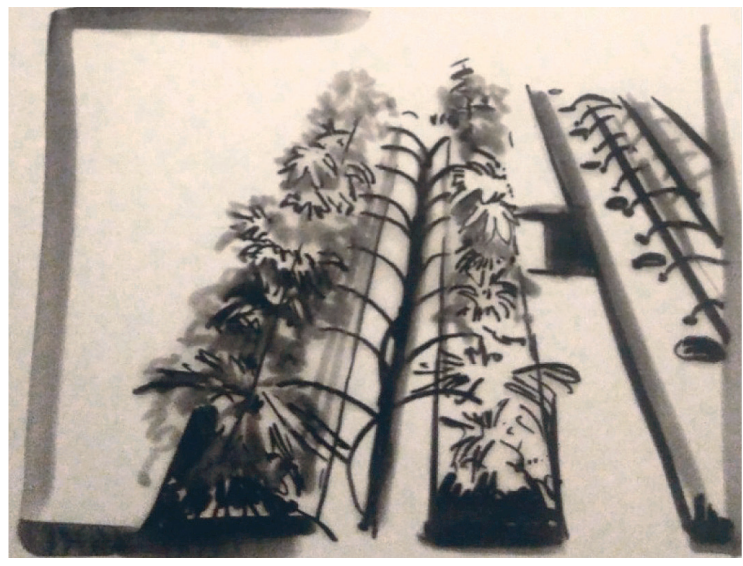

Rys. 4. Uprawa hydroponiczna

Współcześnie prowadzona produkcja roślinności w mieście, uprawa w budynkach bez wykorzystania ziemi, jest realizowana w dwóch rodzajach zabudowy. Pierwszy stanowią adaptowane budynki poprzemysłowe i hale magazynowe, w których, przy spełnieniu określonych kryteriów można prowadzić uproszczone eksperymenty hodowlane i sprawdzać techniczne możliwości realizacji uprawy. Jednakże ograniczenia wynikające z istniejącej zabudowy oraz infrastruktury prawdopodobnie będą wpływać na skuteczność i wydajność produkcji.

Drugim rodzajem istniejących komercyjnych farm miejskich są inwestycje realizowane od początku z założeniem prawy roślin w projektowanym budynku. Budynki planowane są konstrukcyjnie i technologicznie w sposób umożliwiający uprawę roślin oraz zakładany sposób użytkowania budynku. Interdyscyplinarne zagadnienie projektowe stanowi wyzwanie projektowe o realizacyjne, łącząc zagadnienia estetyczne, budowlane, technologiczne, inżynieryjne i środowiskowe oraz ekonomiczne i użytkowe.

\section{Farmy miejskiej jako uzupełnienie struktury funkcjonalno-przestrzennej miasta}

Poszukiwanie odpowiedzi na zagadnienie gdzie i jak realizować produkcję roślin w mieście, jest powiązane z lokalnymi uwarunkowaniami środowiskowymi oraz kontekstem tkanki miejskiej.

(...) Problem pustek (które z czasem zaczęliśmy nazywać nieużytkami miejskimi) staje się dużo bardziej dotkliwy, kiedy miasto zaczyna pustoszeć z innych powodów, niejako naturalnie. Przyczyn tego procesu upatruje się $w$ deindustrializacji, która miała miejsce od lat sześćdziesiatych ubieglego wieku. Zmiany strukturalne w gospodarce powoduja usuwanie z miast albo 
tylko z ich partii centralnych, przedsiębiorstw przemysłowych, wymagajacych znacznych obszarów, na rzecz ustug, na które potrzeba znacznie mniej miejsca. Decentralizacja, uelastycznienie i dywersyfikacja produkcji przemystowej zmniejszaja zapotrzebowanie na przestrzeń $w$ mieście dla tej gatęzi gospodarki. Dominujące uprzednio kryterium bliskości w wyborze lokalizacji produkcji zastapione zostało przez kryterium dostępności, Dzięki rozwojowi logistyki lokalizacja magazynów wewnatrz miasta okazuje się zbędna. Poza terenami poprzemystowymi również nabrzeża i porty, tereny kolejowe, powojskowe, wyludnione osiedla oraz nieużytkowane działki różnych rozmiarów stają się obszarami pozbawionymi swojej funkcji, przynajmniej do czasu pojawienia się nowych użytkowników, co w pewnych przypadkach trwa nawet dekady [23].

We współczesnym mieście problem stanowi nie tyle brak miejsca, co brak środków (funduszy) i rozwiazań (koncepcji) zdolnych zagospodarować rozrastajace się białe plamy na mapie. Owe pustki w mieście to „(...) miejsca nie skolonizowane przez człowieka oraz miejsca, których ani architekci, ani projektanci ich przelotnych a pobieznych użytków nie zamierzaja kolonizować. (...) Pustki to zatem miejsca pozbawione znaczenia, nie dlatego, że sa puste. Przeciwnie, sa puste dlatego, że nie posiadaja znaczenia [24].

Staja się laboratorium dla testowania nowych pomysłów ksztattowania przestrzeni miejskiej. Nieużtki przekształcane sa $w$ miejsca zdarzeń. „,Nowa logika "9 polega zatem na wypetnianiu miejsc znaczeniem [25].

Działania niosące zmiany w przestrzeni miasta nie mogą swą Intensywnościa wyjśś poza przyjęty dla niego poziom, ustalany $w$ procesie ustawicznego planowania i projektowania urbanistycznego, jako harmonijny zwiąek między: środowiskiem zbudowanym $i$ naturalnym oraz pomiędzy nimi obydwoma $i$ potrzebami ekonomicznymi $i$ socjalnymi mieszkańców [26].

Problemom pustki oraz rewitalizacji obszarów zdegradowanych, zaradzić może realizacja rolnictwa miejskiego, innowacyjnej i pro-środowiskowej produkcji żywności na potrzeby społeczności lokalnej w mieście. Ze względów technologicznych i użytkowych, można sformułować podstawowe i uniwersalne wytyczne warunkujące wybór lokalizacji i sposób zagospodarowania terenu, na którym prowadzona będzie produkcja rolna wertykalnej farmie miejskiej. Skala obiektu oraz wielkość terenu opracowania, jak zawsze w obiektach produkcyjnych, uzależnione będą od zakładanej wydajności i różnorodności produkowanych gatunków roślin oraz od programu funkcjonalnego. Zasadne zatem jest pytanie, w jakim stopniu miasto i mieszkańcy powinni być zaopatrzeni w produkty pochodzące z farm miejskich. Odpowiedzi urbanistów wymaga zagadnienie, czy powinno się wskazywać lokalizacje w strategicznych miejskich miejscach węzłowych, czy też należy raczej wprowadzać system rozdrobnionych, mniejszych inwestycji zintegrowanych z lokalnymi centrami usługowymi. Poszukując odpowiedzi niewątpliwie należy rozważyć funkcję i dostępność terenów miejskich dla zabudowy farm miejskich. Rozważenia wymaga propozycja, aby te nowe inwestycje zaliczać nie tylko do budynków produkcyjnych, ale również do obiektów użyteczności publicznej, handlu, kultury, sportu i rekreacji. Określenia wymaga programowanie inwestycji przyszłych farm miejskich w kontekście rozpoznania potrzeb uzupełnienia struktury funkcjonalno-przestrzennej współczesnego miasta.

Rozpatrując kwestię rolnictwa miejskiego i farm miejskich, jako elementu nowej urbanizacji, rozpoznawać należy kolejne dwa rodzaje uwarunkowań realizacyjnych i lokalizacyjnych.

Pierwszym rodzajem uwarunkowań lokalizacyjnych, jest realizacja farmy miejskiej w planowanym mieście typu smart city, realizowanym jako całościowe nowe założenie. 
Oczywiste jest, że zagadnienia tego typu w najbliższym czasie nie będą zbyt powszechne. Jednakże miasto takie jest już planowane i zaczyna być realizowane. Miasto o nazwie CITE [27] (The Centre for Innovation, Testing And Evaluation), powstanie w Nowym Meksyku. Na powierzchni ok. $40 \mathrm{~km}$ powstanie smart city, w którym wdrażane będą nowe technologie. Początkowo w mieście zamieszkają sami naukowcy, który będą testować innowacyjne rozwiązania.

Drugim rodzajem uwarunkowań lokalizacyjnych, jest realizacja inwestycji w istniejącej tkance miejskiej. Realizacja skomplikowanego technologicznie i inżynieryjnie budynku oraz zagospodarowania terenu w środowisku i krajobrazie miejskim o lokalnych i regionalnych uwarunkowaniach środowiskowych, przestrzennych i społecznych. Ujęcia interdyscyplinarnego wymaga ustalenie optymalnej lokalizacji farmy miejskiej w strukturze istniejącego i funkcjonującego miasta ze zdefiniowanymi i funkcjonującymi systemami komunikacji, przestrzeni publicznych oraz zieleni biologicznie czynnych.

Planując inwestycję pojawia się problem wydajności istniejącej infrastruktury oraz dostępności gruntów. Już na etapie planowania lokalizacji oraz programowania inwestycji konieczna jest optymalizacja w zintegrowanym procesie projektowania. Farmy miejskie nie powinny zakłócać działania istniejących struktur i terenów, zadaniem powinno być usprawnianie i rewitalizacja, czyli wprowadzanie na nowo życia - sił witalnych w przestrzeni miejskiej, lokalnej gospodarce oraz społeczności.

Tereny i zabudowa farm miejskich powinny zatem być wkomponowane w strukturę miasta, przy założeniu, że będą one dominantą przestrzenną i elementem krystalizującym przestrzeń i system komunikacji. Program i struktura funkcjonalna terenu i zabudowy, generować będą przekształcenia środowiska przyrodniczego i krajobrazu miejskiego w powiązaniu z przemianami społecznymi. Rolnictwem, produkcją pożywienia i pozostałych dóbr wytwarzanych w terenie i budynkach będą zajmować się inżynierowie i technolodzy. Nowe ogniwo w społeczeństwie wiedzy i informacji.

W rozwiniętych społecznie i gospodarczo miastach układ jednofunkcyjnych jednostek strukturalnych ulega stopniowemu zacieraniu na rzecz wyodrębniania się jednostek wielofunkcyjnych [28] Integracja kilku funkcji w strukturze farmy miejskiej łączy się z rozwojem nowych form kształtowania struktury miejskiej w procesie rewitalizacji terenów zurbanizowanych. Wskazane jest zatem kształtowanie wielofunkcyjnych „hybrydowych” rozwiązań przeznaczenia i zagospodarowania terenu oraz zabudowy farm miejskich. Analiza zagadnienia prowadzi do autorskich wniosków, wskazujących, że funkcja produkcyjna powinna zatem zostać uzupełniona o funkcje:

1. sportu i rekreacji (zagospodarowanie terenu oraz zaplecze sanitarne i szatnie),

2. kultury (amfiteatr, sale koncertowe i wystawowe) oraz wystawy plenerowe,

3. gastronomii (restauracje korzystające z produktów z farmy, przetwarzanie produktów),

4. handlu (lokale sprzedaży detalicznej i hurtowej),

5. konferencyjne i szkoleniowe (dla promocji i edukacji),

6. biurowe (dla przedsiębiorstw współpracujących przy produkcji i transporcie),

7. nauki (laboratoria i ośrodki badawcze szkolące pracowników, rozwijające technologię),

8. hotelowe (baza noclegowa dla naukowców oraz osób związanych z obsługą farmy),

9. przestrzeni publicznych (urządzone, częściowo zadaszone, powiązane z zielenią).

Kształtowanie budynku lub zespołu budynków wielofunkcyjnych o dominującej funkcji produkcyjnej, motywowałoby działania rewitalizacyjne miasta i integracje społeczną. 
Powstanie farmy miejskiej mogłoby być impulsem do organizacji centrum lokalnego lub rozwoju strefy śródmiejskiej, w zależności od lokalizacji i założeń inwestycyjnych.

Podstawowy program struktury funkcjonalno-przestrzennej zabudowy farmy miejskiej lub zespołu zabudowy jednostki urbanistycznej na potrzeby rolnictwa miejskiego, powinny zostać uzupełniane o zabudowę i urządzenia na potrzeby funkcji usług, zwłaszcza handlu i gastronomii.

Obiekty i teren służący do produkcji i wykorzystania zieleni, powinny umożliwiać realizację funkcji sportu i rekreacji mieszkańców miasta. Czyli funkcje w których realizacja zieleni i wody jest podstawą opracowania. Wówczas elementem zagospodarowania terenu powinny być place zabaw dla różnych grup wiekowych, Skate Park lub inne urządzenia terenowe umożliwiające rekreację czynną i uprawianie sportów w terenie (bieganie, wspinaczka, jazada na rowerze, itd.).

W związku z wykorzystaniem wody jako podstawowego nośnika minerałów w produkcji roślin, wskazane jest aby w terenie realizować tężnie solankowe, jako inhalatorium na wolnym powietrzu.

Prognozować można, rozwój i upowszechnienie zabudowy farm miejskich, jako ośrodków integrujących przestrzenie publiczne z usługami i produkcją na rzecz społeczności lokalnej.

Funkcją uzupełniającą program terenu farmy miejskiej, powinna być kultura i wydarzenia społeczne, realizowane $\mathrm{np}$. w amfiteatrze, na skwerach oraz przestrzeniach wystawowych.

Programując teren wokół farmy miejskiej, zasadne jest również zaplanowanie zbiornika wodnego lub systemu zbiorników wodnych i kanałów z napowietrzaną wodą płynącą. W celu podniesienia efektywności, wydajności oraz atrakcyjności farmy miejskiej, wskazane jest uwzględnienie w programie funkcjonalnym zagospodarowania terenu na potrzeby hodowli zwierząt uzupełniających funkcje produkcyjne, tj., hodowli kur, kóz, ryb, owiec.

Wskazane jest aby funkcję produkcyjną łączyć z użytecznością publiczną sportem i rekreacją zintegrowanymi z przestrzeniami publicznymi realizowanymi z zielenią użytkową i ozdobną. Optymalizując przepływ energii wykorzystywano by zamknięte obiegi materii w technologii produkcji oraz uwarunkowania gospodarki rynkowej - obrotu towarem, wytworzonym dobrem przy optymalizacji nakładów i minimalizacji transportu.

Kształtowane w ten sposób „hybrydowe” ośrodki produkcyjno-usługowe stanowiły by uzupełnienie struktury funkcjonalno-przestrzennej struktury miasta. Będąc obiektami użyteczności publicznej dostępnych z ukształtowanych przestrzeni publicznych stawałyby się impulsem rozwoju więzi społecznych a tym samym rewitalizacji terenów zdegradowanych przestrzennie i środowiskowo. Lokalizacja w miejscach węzłowych, w powiązaniu z systemem komunikacji, systemem zieleni oraz systemem przestrzeni publicznych z pewnością sprawiałoby, że farmy miejskie będące realizacją rolnictwa miejskiego, byłyby elementem scalającym strukturę miasta kształtowanego w sposób uwzględniający zasady harmonijnego rozwoju z wykorzystaniem innowacyjnych technologii i ideologii.

\section{Podsumowanie}

Rolnictwo miejskie definiowane jest jako zagospodarowanie terenu i zabudowa realizowana do produkcji roślin na potrzeby społeczności lokalnej. Jest istotnym elementem nowej urbanizacji, a tym samym Nowej Urbanistyki i powinno stanowić przedmiot zainteresowania współczesnych planistów i strategów. Sprawa nie dotyczy po prostu planowania 
przestrzennego, urbanistyki czy architektury, ale jest związana z umiejętnością budowy świata przyszłości. [29]

Warto na początek zorientować się, jak świat, życie ludzi, życie miast $i$ wsi, sprawy ekonomii, wojny i pokoju, wysokiej i niskiej kultury, nauki i innych jeszcze determinant rozwoju, widziane sa przez osoby spoza kręgu planistów przestrzennych. Warto śledzić nie tylko prace naukowe, ale i reagująca ,, na goraco” publicystykę [30].

Tym samym wskazane jest analizowanie możliwości realizacyjnych farm miejskich wprowadzających produkcję żywności metodami innowacyjnymi i zintegrowanymi z zabudową. Postęp myśli i technologii może przynieść nowe rozwiązania produkcyjne, konieczne jest zatem aby planowanie miasta współtworzyło rozwój cywilizacyjny, a nawet wyprzedzało w swych wizjach i rozstrzygnięciach przestrzennych. Planowanie miasta polega na sterowaniu koncentracją, czyli rozstrzyganiu dylematu: przebudowa dla intensyfikacji versus ekspansja terytorialna. Decyzji tych nie można podejmować racjonalnie bez analizy chtonności terenów budowlanych, czyli badania realnych możliwości rozwijania tych nieruchomości, które leża na terenach już uzbrojonych $w$ infrastrukture [31].

Metody uprzemysłowione produkcji roślin w mieście realizowane są w wertykalnych farmach miejskich.. Dla zachowania środowiskowej równowagi przestrzeni miejskich oraz powiązań dotyczących współistnienia architektury i zieleni w mieście, konieczne jest powiązanie farm miejskich z systemem zieleni publicznej. W budynku stosować należy rozwiązania umożliwiające wprowadzanie zieleni powierzchni biologicznie czynnej na ścianach i dachach budynków. Tym samym innowacyjność funkcji i technologii produkcji roślin łączona byłaby $z$ innowacyjnymi rozwiązaniami realizacji ozdobnych powierzchni biologicznie czynnych, zieleni zintegrowanej z zabudową. Stanowiąc uzupełnienie systemu zieleni miejskiej oraz wpływając na świadome kształtowanie parametrów środowiska miejskiego i ekosystem miejski. Wprowadzanie rozwiązań „hybrydowych” obiektów wielofunkcyjnych o dominującej funkcji produkcji żywności możliwe jest kształtowania synergicznych układów przestrzennych poprzez integrację przestrzeni miejskiej i zabudowy o innowacyjnej funkcji produkcji - farmy miejskiej - stanowiącej uzupełnienie struktury funkcjonalnej miasta $\mathrm{w}$ powiązaniu z kształtowaniem przestrzeni publicznych.

Architektura pro-środowiskowa powiązana z technologiami umożliwiającymi produkcję roślin w budynkach, umożliwia integrację przestrzeni miejskiej uzupełniając strukturę funkcjonalno-przestrzenną miasta. Jednym z najważniejszych problemów urbanistyki wspótczesnej $w$ dziedzinie kompozycji zieleni staja się obszary zabudowy intensywnej, czyli problem krajobrazu miejskiego na terenach pozbawionych walorów przyrodzonych, w zespołach wielkomiejskich, gdzie zadanie urbanistyczne polega na tworzeniu czy ksztattowaniu przestrzeni złożonej zarówno z zespołów architektonicznych jak $i$ z zieleni. Rola zieleni w zespotach urbanistycznych staje się tym większa, że skala potrzeb inwestycyjnych powoduje konieczność stosowania budownictwa masowego, uprzemysłowionego o dość ograniczonych, jak dotąd, możliwościach indywidualnego kształtowania architektury budynków. Kompozycja zieleni w takich zespołach urbanistycznych może mieć jednak cechy indywidualne [32].

Jednocześnie jednak trudności paliwowe oraz zatłoczenie dróg spowoduje, że coraz większa popularnościa będa się cieszyty dobrze zorganizowane tereny wypoczynku i rekreacji czynnej położone blisko miasta lub nawet na jego terenie. Dlatego téz kształtowanie takich terenów staje się tematem niezwykle aktualnym i społecznie potrzebnym [33].

Drugą wskazówką jest to, że bez względu na to jak dalece rozproszenie się posunęto, ciagle w owej pustej przestrzeni widać wielkie ilości terenów zielonych. Wydaje się, że ten fakt powinien być wykorzystany - przecież przenosimy się na peryferia w poszukiwaniu zie- 
lonego habitatu. Wychodząc z takiego założenia, powiedzieć można, że ziemia rolna, której uprawianie wokót miast przestaje mieć uzasadnienie ekonomiczne, stawać się powinna miejskim (gminnym) zasobem wspólnej, zielonej, otwartej przestrzeni [34].

Zasadne jest zatem aby zagadnienie rolnictwa miejskiego było przedmiotem badań interdyscyplinarnych i powinno być zagadnieniem analizowanym przez architektów i urbanistów. Zjawisko wprowadzania produkcji żywności do miasta jest istotne dla programowania i planowania struktur miejskich w dalekosiężnych planach. Idea rolnictwa miejskiego nie została przyjęta jeszcze $w$ żadnej polityce $w$ naszym kraju, $w$ tym polityce rolnej czy rozwoju przestrzennego miast. Rodzinne ogródki działkowe jako jedyne można uznać za przejaw rolnictwa miejskiego szeroko rozpowszechnionego na terenie Polski. Jednakże termin „rolnictwo miejskie" nie jest używany w kontekście swojego znaczenia w publikacjach i regulacjach prawnych $w$ Polsce [35].

Oczywiste jest, że technologia produkcji oraz program i struktura zabudowy farmy miejskiej stanowić powinny przedmiot badań i analiz,gdyż jedynie kształtowania zabudowy zintegrowanej z przestrzenią miejską daje podstawę powodzenia inwestycyjnego. Zatem program funkcjonalny farmy i obiektów towarzyszących odpowiadać powinny zapotrzebowaniom społecznym i rynkowym. Wskazuje się na konieczność realizacji w mieście produkcji dóbr materialnych i niematerialnych powstających w zespole farmy miejskiej. Określając przeznaczenie terenu i wskaźniki zagospodarowania wskazać należy zabudowę o funkcji użyteczności publicznej oraz dostępności dla społeczności lokalnej przestrzeni publicznych i terenów rekreacji z zielenią towarzyszącą i zintegrowaną z budynkami. Tym samym podkreślenia wymaga powiązanie inwestycji farmy miejskiej z systemem przestrzeni publicznych, co powoduje, że tereny i zabudowa na potrzebę rolnictwa miejskiego w wielofunkcyjnych farmach miejskich, stanowi element scalający strukturę miasta. Z tego powodu powinna być realizowana $\mathrm{w}$ miejscach węzłowych $\mathrm{w}$ powiązaniu z systemami: komunikacji drogowej, przestrzeni publicznych oraz zieleni miejskiej.

Farmy miejskie nie powinny zakłócać działania istniejących struktur i terenów, zadaniem powinno być usprawnianie i rewitalizacja, czyli wprowadzanie na nowo życia - sił witalnych - w przestrzeni miejskiej, lokalnej gospodarce oraz społeczności. Tereny i zabudowa farm miejskich powinny zatem być wkomponowane w strukturę miasta, przy założeniu, że będą one dominantą przestrzenną i elementem krystalizującym przestrzeń, system komunikacji. Program i struktura funkcjonalna terenu i zabudowy, generować będą przekształcenia środowiska przyrodniczego i krajobrazu miejskiego w powiązaniu z przemianami społecznymi. Rolnictwem miejskim - produkcją pożywienia i pozostałych dóbr wytwarzanych w terenie i budynkach będą zajmować się inżynierowie i technolodzy, stanowiący „nowe ogniwo” w społeczeństwie wiedzy i informacji.

Indywidualnych decyzji wymaga, to jakie cechy środowiska i działalności człowieka powinny być eksponowane w kompozycji krajobrazu miejskiego formowanego na terenie przeznaczonym dla rolnictwa miejskiego realizowanego w budynkach farm miejskich. Opisana typologia farm miejskich została przedstawiona w celu określenia potencjalnych kierunków rozwoju i wytycznych do twórczych działań projektowych. Szczególnie istotne wydaje się wprowadzanie w struktur miasta hybrydowych obiektów wysoce wyspecjalizowanych i wyposażonych w nowe po-środowiskowe technologie. Jednym z podstawowych postulatów kreowania zabudowy produkcyjnej - przemysłowej - powinna być atrakcyjność formy i wyrazu estetycznego zabudowy, która w odbiorze powinna być postrzegana jak budynek użyteczności publicznej, zachęcając do użytkowania i korzystania z produkcji, gdzie elementami kompozycyjnymi i użytkowymi są roślinność i woda. 
W podsumowaniu wskazać należy, że rolnictwo miejskie jest wprowadzane jako produkcja żywności z wykorzystaniem innowacyjnych technologii. Realizując podstawowe funkcje produkcyjne oraz zalecane funkcje uzupełniające wykazano, że zagospodarowanie terenów i budynków farmy miejskiej stanowić powinny element scalający i uzupełniający strukturę funkcjonalno-przestrzenną miasta. Realizacja w miejscach węzłowych hybrydowych zespołów i jednostek urbanistycznych farm miejskich powinna być przedmiotem analiz i dyskusji interdyscyplinarnych z udziałem architektów i urbanistów odpowiedzialnych za planowanie i kierunki zagospodarowania przestrzennego w mieście.

\section{Literatura}

[1] Wowrzeczka B. Agropolis - część II. Wspótczesna farma miejska. Architectus, 2014.

[2] Ryńska E.D. Zintegrowany proces projektowania pro środowiskowego. Projektant a środowisko. Oficyna Wydawnicza Politechniki Warszawskiej, Warszawa 2012, str. 20.

[3] Gzell S. Wyktady o wspótczesnej urbanistyce. Oficyna Wydawnicza PW, Warszawa 2015, str. 86.

[4] Gzell S. Wykłady o wspótczesnej urbanistyce. Oficyna Wydawnicza PW, Warszawa 2015, str. 85.

[5] Gzell S. Wykłady o współczesnej urbanistyce. Oficyna Wydawnicza PW, Warszawa 2015, str. 32.

[6] Chmielewski J.M. Teoria urbanistyki w projektowaniu i planowaniu miast. Oficyna Wydawnicza PW, Warszawa 2010, str. 25.

[7] Skibniewska H. Miasto a jakość życia. Hipoteza ekologii uniwersalistycznej. Centrum Uniwersalizmu przy Uniwersytecie Warszawskim Polska Federacja Życia, Drukarnia Jerzego Kosińskiego, Warszawa 1999 r, str. 232- 233.

[8] Chmielewski J.M., Teoria urbanistyki w projektowaniu i planowaniu miast, Oficyna Wydawnicza PW, Warszawa 2010, str. 410.

[9] Wines J. Zielona Architektura. Taschen wydanie polskie TMC Art., 2008 rok, str. 8.

[10] Wines J. Zielona Architektura. Taschen wydanie polskie TMC Art., 2008 rok, str. 9.

[11] Wines J. Zielona Architektura. Taschen wydanie polskie TMC Art., 2008 rok, str. 14.

[12] Skibniewska H. Miasto a jakość życia. Hipoteza ekologii uniwersalistycznej. Centrum Uniwersalizmu przy Uniwersytecie Warszawskim Polska Federacja Życia, Drukarnia Jerzego Kosińskiego, Warszawa 1999 r, str. 232- 233.

[13] Ryńska E.D. Zintegrowany proces projektowania pro środowiskowego. Projektant a środowisko. Oficyna Wydawnicza Politechniki Warszawskiej, Warszawa 2012, str. 29.

[14] Wines J. Zielona Architektura. Taschen wydanie polskie TMC Art., 2008 rok, str. 19.

[15] http://www.nowaswiadomosc.pl/421-czy-czeka-nas-glod.html

[16] http://www.nowaswiadomosc.pl/284-technologia-nasa-w-ogrodzie.html

[17] http://www.nowaswiadomosc.pl/645-farmy-miejskie-warzywa-i-owoce-doslownie-w-zasiegu-reki.html

[18] Czarnecki M. Rolnictwo przenosi się do miast. http://wyborcza.pl/1,76842,15191703,Rolnictwo_ przenosi_sie_do_miast_Jak_dziala_miejska.html?disableRedirects=true

[19] http://dekoeko.com/miejskie-farmy-na-swiecie/

[20] http://ulicaekologiczna.pl/technologie/miejska-farma-w-srodku-biurowca/

[21] http://www.sciencealert.com/this-indoor-farm-is-100-times-more-productive-than-an-outdoor-one autor: FIONA MACDONALD, 13 JAN 2015.

[22] http://www.independent.co.uk/environment/aerofarms-work-starts-to-build-worlds-largest-verticalurban-farm-in-newark-10211245.html

[23] Gzell S. Wykłady o wspótczesnej urbanistyce. Oficyna Wydawnicza PW, Warszawa 2015, str. 132-133.

[24] Gzell S. Wykłady o współczesnej urbanistyce. Oficyna Wydawnicza PW, Warszawa 2015, str. 135.

[25] Gzell S. Wykłady o współczesnej urbanistyce. Oficyna Wydawnicza PW, Warszawa 2015, str. 136.

[26] Gzell S. Wykłady o współczesnej urbanistyce. Oficyna Wydawnicza PW, Warszawa 2015, str. 143.

[27] http://www.nowaswiadomosc.pl/149-nowe-miasto-nie-dla-zwyklych-ludzi.html 
[28] Chmielewski J.M. Teoria urbanistyki w projektowaniu i planowaniu miast. Oficyna Wydawnicza PW, Warszawa 2010, str. 38.

[29] Gzell S. Wykłady o współczesnej urbanistyce. Oficyna Wydawnicza PW, Warszawa 2015, str. 32.

[30] Gzell S. Wykłady o wspótczesnej urbanistyce. Oficyna Wydawnicza PW, Warszawa 2015, str. 86.

[31] Bielecki Cz. Sztuka budowania współczesny paradygmat. Oficyna Wydawnicza PW, Warszawa 2013 r., str. 115.

[32] Wejchert K. Elementy kompozycji urbanistycznej. Warszawa 1984, str. 226-227.

[33] Wejchert K. Elementy kompozycji urbanistycznej. Warszawa 1984, str. 248-249.

[34] Gzell S. Wykłady o wspótczesnej urbanistyce. Oficyna Wydawnicza PW, Warszawa 2015, str. $33-34$.

[35] Szulczewska B., Bruszewska K. Urban agriculture in the city of Warsaw, Poland. Warszawa, 2013, http://www.urbanagricultureeurope.la.rwth-aachen.de/mediawiki/images/0/0f/Warsaw_reference region.pdf

\title{
Urban agriculture as an innovative production constitutes an element that integrates and complements the city's structure
}

\author{
Magdalena Grochulska-Salak
}

Faculty of Architecture, Warsaw University of Technology, e-mail:m.grochulska-salak@o2.pl

\begin{abstract}
Urban agriculture is defined as development for the production of plants for the needs of the local community. The presented problems concern the shaping of buildings together with the green systems in order to preserve the environmental balance of urban spaces and the connections between the coexistence of architecture and greenery in the city. It is pointed out the possibility of shaping synergistic spatial arrangements by integrating urban space and development with an innovative production function - urban farm - complementing the functional structure of the city in connection with the shaping of public spaces and the green system. Pro-environmental architecture is linked to technologies that enable plant production in buildings to integrate urban space, complementing the city's functional-spatial structure. The implementation of new technologies enables the production of plants in hydroponic and aerospace buildings. The technology of production and the program and structure of urban farm buildings are the subject of research and analysis, in order to shape integrated urban space development in the context of the urban unit's autarky. It is pointed out the need to increase the scope of production of material and non-material goods realized in the team of urban farm. Linking with public spaces and realization of public utility buildings is justified by shaping the land development and development program for the needs of the local community. Urban agriculture can be an element that integrates the city's structure. It should be implemented in nodal areas in connection with the systems of: road communication, public spaces and urban greenery.
\end{abstract}

Keywords: Harmonious development, new urban planning, urban agriculture, urban farming, Vertical farms, green architecture. 